\title{
Slavic Dialectology: A Survey of Research since 1989
}

\author{
Marc L. Greenberg, Krzysztof E. Borowski, \\ Joseph Schallert, and Curt F. Woolhiser
}

Abstract: The last 25 years in Slavic dialectology mark the period not only of JSL's founding but also of major and multiple political, social, and economic reorganizations in predominantly Slavic-speaking states. During this period research institutions and their priorities and projects have both continued and changed; technological innovation has meant moving towards electronic dissemination, "digital humanities," and innovative modes of presenting research data and findings. In some cases major works (e.g., dialect atlases) have advanced during this period. Moreover, a new generation of scholars has had greater opportunities for mobility and therefore exposure to a variety of linguistic frameworks and approaches, which has fostered cross-border collaboration in the field. The present essay gives an overview of progress made on dialect projects both created institutionally and individually and including both traditional (book, article) and new digital means of dissemination.

\section{Introduction}

In the first 20 years of the Journal of Slavic Linguistics (JSL) only 6 papers (excluding book reviews) out of ca. 240 , or $2.5 \%$, contain the word "dialect" in the title (JSL Editors 2012). This statistic perhaps says more about the North American center of gravity of JSL, with its focus on Slavic synchronic issues and standard languages, than the dynamism of research on dialectology, which because of its source in in situ variation, is conducted primarily in Europe. Following the received view, the bulk of descriptive work tends to be done by scholars working for institutions charged with cataloging language variation associated with the titular language, while non-Slavic scholars' work tends to focus on interpretation, with many exceptions on both sides. Alexander's review of about a century of Slavic dialectological studies, with its bibliography divided between "Works by Slavic/European scholars" and "Works by North American scholars" bears out this dichotomy (2006: 38-43, 43-52). Picking up the thread of Alexander's overview from a decade ago, our collective focuses on important trends and developments in the most recent period in a more abbreviated fashion, in part owing to the short format of this essay. 
The last 25 years in Slavic dialectology mark both the period of time not only of JSL's founding as well as of major and multiple political, social, and economic reorganizations in predominantly Slavic-speaking states. During this period research institutions and their priorities and projects have both continued and changed; technological innovation has meant moving towards electronic dissemination, "digital humanities," and innovative modes of presenting research data and findings. In some cases major works (e.g., dialect atlases) have advanced during this period. Moreover, a new generation of scholars has had greater opportunities for mobility and therefore exposure to a variety of linguistic frameworks and approaches, which has fostered cross-border collaboration in the field.

In this brief survey, it is not possible to provide a complete overview of the copious literature. To be selective, we have relied on four area experts to cover specific regions and then joined forces to cover broader, pan-Slavic works. The rest of the article is divided into five sections: All-Slavic and regional works, West Slavic, Western South Slavic, Eastern South Slavic, and East Slavic. ${ }^{1}$ Generally, these divisions map well onto the way that the regions are treated both institutionally and in bibliographic treatments.

\section{All-Slavic and Regional Works}

Here we refer mainly to publications which have not appeared in the supranational projects ALE (Atlas Linguarum Europae), OLA (Obščeslavjanskij lingvističeskij atlas), and OKDA (Obščekarpatskij dialektologičeskij atlas), except to note the salutary news that these ambitious projects continue to publish their materials and are available freely on the Internet. Recent linguistic scholarship published since 2000 which uses dialect evidence to explore inter-Sl and $\mathrm{CSI}^{2}$ connections does so chiefly on the basis of lexicology (overlapping in part with derivational morphology) but also draws upon accentual and phonological data. The most notable contributions in our estimation have been made by Russian scholars.

In lexicology, of particular note are three monographs: Kurkina 1992 and Vendina 2009 and 2014. Kurkina (a Moscow-based Slovene specialist) focuses chiefly on W SSI but makes wide use of published material from other Slavic dialects, grouping the data according to root vocalism, ablaut, and isogloss

1 Supplemental bibliographical materials that did not fit in this concise survey are archived in the KU ScholarWorks digital repository at: http://hdl.handle.net/1808/24598.

2 The following abbreviations are used in the text: $\mathrm{Ba}=$ Baltic, $\mathrm{Bg}=$ Bulgarian, $\mathrm{Bos}=$ Bosnian, $\mathrm{Br}=$ Belarusian, $\mathrm{C}=$ Central, $\mathrm{Cr}=$ Croatian, $\mathrm{CSl}=$ Common Slavic, $\mathrm{Cz}=\mathrm{Czech}$, $\mathrm{ESl}=$ East Slavic, $\mathrm{Mac}=$ Macedonian, $\mathrm{Mo}=$ Montenegrin, $\mathrm{Po}=$ Polish, $\mathrm{Ru}=$ Russian, Sk = Slovak, $\mathrm{Sl}=$ Slavic, $\mathrm{Sn}=$ Slovene, $\mathrm{Sr}=$ Serbian, $\mathrm{SSl}=$ South Slavic, Uk = Ukrainian, $\mathrm{WSl}=$ West Slavic 
patterns, although without referring to maps (note that only vol. 1, Životnyj mir, of OLA had yet appeared before 1992). Vendina 2009 applies the isogloss typology developed by Borodina in the 1970s and 1980s to Russian core agrarian lexical stock, with extensive comparison to the rest of Slavic, projecting the results onto 111 maps. Continuing in the same tradition, Vendina 2014 is a major cumulative work which makes extensive use of dialect geography from a pan-Slavic perspective, with 216 maps based on the entire OLA Slavic dialect point network.

In phonology, Nikolaev, Ter-Avanesova, and Tolstaja 2013 provides a detailed analysis of Polesian vocalism from the CSl perspective in terms of origins from reconstructed CSl tribal dialects, operating with the nomenclature and dialect groupings elaborated by the Moscow Accentological School (MAS), chiefly Nikolaev.

In accentology, two major earlier works by scholars of the MAS make extensive reference to the dialectal distribution of Slavic accentual patterns, while proposing a new classification of early Slavic dialects, aspects of which have provoked considerable controversy in the field (see Dybo, Zamjatina, and Nikolaev 1990 [with 2 maps], 1993). An example of a more recent work in this vein is Nikolaev 2008, a monograph-length article which is devoted chiefly to Carpathian and Pskov-Polotsk dialect material, but which also contains useful tabular material on several other Slavic dialects which provide possible direct evidence for a fourth CSl accent paradigm (d).

Elsewhere, Nikolaev 2012 (with 3 maps) synthesizes chiefly accentual, but also phonological, morphological, and lexical traits (the latter with reference mainly to Mladenov 1975) to establish shared archaic isoglosses between W and E Galician dialects, on the one hand, and E Bg and W Bg dialects, on the other, while Tolstaja 2012 represents a significant contribution to the study of Slavic clitics from the comparative (Carpathian-SSl) perspective, focusing on the Hutsul dialect of Synevyr, for which abundant fieldwork evidence is provided.

\section{West Slavic}

In post-1989 WSI dialectological research, traditional approaches are being supplemented with methods that cross over into related disciplines (e.g., sociolinguistics) as some scholars have turned to sociolinguistically oriented dialectology. Linked to this turn are investigations of diasporic communities and their dialects through the lens of contact linguistic phenomena (e.g., bi-/multilingualism, borrowings). Finally, a rising interest in local culture sensu lato (cf. the idea of mata ojczyzna 'little homeland') has enabled local activists and organizations to participate in vernacular documentation through nonacademic publications. 
In the last 25 years, major advances have been made in two traditional areas of dialectologists' activity: atlases and dictionaries. The Czech Linguistic Atlas (Český jazykový atlas [ČJA], Balhar and Jančák 1992-2011) represents a major achievement of modern-day $\mathrm{Cz}$ dialectology. The main body of the Atlas has been published in five volumes (1992-2005); an additional volume (Dodatky, 2011) includes a bibliography of post-1968 dialectological works, from books and articles to dissertations and theses. In a variationist sociolinguistic vein, ČJA registers dialectal features of speakers focusing on two variables: age (oldest/middle-aged/youngest) and residence (rural/urban). Further, diasporic $\mathrm{Cz}$ varieties spoken in Poland, Romania, and the former Yugoslavia are also included. Published in hard copy (with a selection of audio recordings) and electronically, the Atlas is available free of charge at http://cja.ujc.cas.cz. Polish dialectology has seen the publication of a four-volume atlas (Dejna and Gala 1998-2002) with an emphasis on morphological and phonetic characteristics. In the 1990s and 2000s, regional dialect atlases of Greater Poland (Sobierajski 1979-2005, 11 volumes), Mazovia (Horodyska-Gadowska, Kowalska, and Strzyżewska-Zaremba 1971-1992, 10 volumes), and Silesia (Zaręba 19691996, eight volumes) have been completed. The 15-volume Sorbian Linguistic Atlas (Faßke, Jentsch, and Michalk 1965-1996) represents a major achievement of Sorbian dialectologists. Finally, a bilingual atlas of Sk dialects in Hungary with data from 48 locales has been published as well (Király 1993).

For the purpose of this chapter, some 80 lexicographic publications have been consulted. In this set, two lines of research can be distinguished: academic and popular, both in origin and audience. Below, only representative examples of the two kinds are included.

The Cz dialect dictionary (Slovník nářeč́ českého jazyka, SNČJ) is yet to be completed. According to plans, SNČJ will include dialect vocabulary from the last 150 years. The first version, with some 7,000 entries (A-C, searchable through an engine and a word index), appeared online at http://sncj.ujc.cas.cz in February 2016. In the electronic version, tokens include definitions as well as examples and places of usage. Along with the Atlas, the dictionary will become part of a digital compendium of $\mathrm{Cz}$ dialectology, in which ČJA and SNČJ entries are cross-listed with Bohemian, Moravian, and Czech Silesian toponyms.

The Slovník slovenských nárečí (Ripka and Ferenčiková 1994-, two volumes) represents the major, although yet unfinished, achievement of Sk dialectal lexicography. Complementary to it are dictionaries of local dialects (Šariš, Zahorie), and Sk dialects spoken in the diaspora (Romania, Ukraine). As in Slovakia, the publication of a comprehensive nationwide dictionary of Po dialects (Karaś et al. 1979-) is ongoing, while a shorter (10,000 tokens) version has already been published (Wronicz 2009).

In the meantime, Po dialectology has seen an increased production of regional and local dictionaries. Of those, about a dozen are devoted to 
Kashubian (for instance, a six-volume etymological dictionary by Boryś and Popowska-Taborska, 1994-2010) and Silesian (for instance, Wyderka 2000-). In a 21,000-token dictionary of the Po Orava dialect, Kąś (2003) combines academic rigor with an intent to promote the local culture to a wider audience. Since iconography is part and parcel of the dictionary, this publication demonstrates how novel presentation techniques can be harnessed for the purpose of popularizing dialect data. For a bibliography, overview, and typology of Po dialectal lexicography, see Karaś 2011.

A dictionary by Dragan (2014) represents the popular line of dialectological research. Published with the help of European Union funding, the dictionary combines lexicography with folklore, as the author utilizes iconography to represent local culture, from cuisine and farming to personal traits and courtship. Additionally, the publication comes with a CD that contains video clips produced with the assistance of the two communities studied. In the clips, locals wear traditional attire, speak local varieties, and star in short scenes that touch on a variety of topics: bread baking, gardening, harvesting, etc. Dragan's dictionary represents but one example in a broader stream of non-academic publications; for an overview of amateur dictionaries of Po dialects, see Wronicz 2006.

Unlike dictionaries, ethnolinguistic works that make use of WSl dialect data remain scarce. In a notable exception, Bartmiński (1996-2012, 14 volumes) provides an extensive account of folk stereotypes and symbols, drawing from dialectology, folklore studies, and ethnographic research. On a smaller scale, other authors focus on demonological lexicon (Dźwigoł 2004) or dialect vocabulary in religious ceremonies (Grabka 2012).

Since the 2000s, much corpus linguistic work has been completed within the framework of the Czech National Corpus. As of May 2017, among the more than 30 corpora are those of contemporary spoken Cz (ORAL 2006, ORAL 2008, ORAL 2013) as well as of the Brno (BMK) and Prague (PMK) urban dialects (Křen 2017). A nationwide dialect corpus (DIALEKT) is yet to be released. While these initiatives bring $\mathrm{Cz}$ dialectology to the fore in the process of digitization of large corpora, other WSI dialectologies are yet to catch up. In Slovakia, work on a digital dialect corpus is underway, but has been hampered by personnel shortages and other obstacles (Šimková 2013). While some Polish scholars have called on their colleagues to start working on a nationwide dialect corpus, digitization of dialect data remains one of the major tasks that Po-and WSl dialectology in general-face in the new century. For now, two online compendia of Po dialects must suffice: Dialektologia polska (http://www.dialektologia.uw.edu.pl) and Gwary polskie (http://gwarypolskie. uw.edu.pl), edited by Halina Karaś and created with the financial support of the Ministry of Culture and National Heritage. These compendia are divided into chapters corresponding to the main dialectal areas. Given the breadth of the material included, from dialectal texts and detailed literature reviews 
to lexicons, maps, and photographs, the compendia can be used by students, scholars, and laypersons.

While there is a fair degree of methodological and theoretical mixing in post-1989 WSl dialectology, the documentation of local varieties still represents the dominant approach. Lexicographic works and descriptions of the morphology, phonetics, and phonology of local varieties account for some 80 percent of the publications consulted for this section. The remaining 20 per cent is occupied by research that transcends the traditional scope of dialectology, and borrows methods from contact linguistics, pragmatics, and sociolinguistics (Burska-Ratajczyk 2013, Kurek 1990, Labocha 1997, Zakhutska 2015). Works that build on dialectological fieldwork to inform historical linguistic research represent yet another line of research. In this vein, Holub and Greenberg (2013) provide an impetus for a renewed interest in the West Pannonian-West SSl continuum through Bohemian-Sn parallels in accentuation. Like perceptual dialectology, urban dialectology remains by and large on the margins of WSl dialectological research.

\section{Western South Slavic}

Dialectological output in the successor states of Yugoslavia-Slovenia, Croatia, Bosnia and Herzegovina, Serbia, and Montenegro ${ }^{3}$ - presents a heterogeneous picture, conditioned by circumstances in each of the states. In areas where the conflicts of the 1990s have had less impact, progress on dialectological projects has been more rapid. Of special note are not just the advancement of major projects, such as dialect atlases, which we will comment on below, but also modes of dissemination that bring free and open access to worldwide users through curated digital repositories and searchable databases. Of note is the Croatian project Hrčak: Portal znanstvenih časopisa Republike Hrvatske (http://hrcak.srce.hr/), which as of 25 July 2016 contains more than 400 scholarly journals and 153,000 articles and other works, of which more than 40 periodicals are listed under "philology". This republic-level scientific digital repository, launched in 2006, contains electronic objects (mainly PDFs of journal articles), searchable by item and keyword using Dublin Core metadata standards, including complete retrospectives and up-to-date contents from key series with significant dialectological and related content, e.g., Croatica et Slavica Iadertina, Čakavska rič, Filologija, Folia onomastica Croatica, Hrvatski dijalektološki zbornik, Kaj, Rasprave: Časopis Instituta za hrvatski jezik i jezikoslovlje, and Zbornik radova Filozofskog fakulteta $u$ Splitu. Noteworthy is also the recent

3 M. L. Greenberg expresses his gratitude to Novica Vujović (Department of Montenegrin Language \& Literature, Cetinje), who kindly provide context and updates on developments in Mo dialectological research. 
initiative of the Fran Ramovš Linguistic Institute (Scientific Research Centre, Slovene Academy of Sciences \& Arts), Fran (http://fran.si), which pays homage to the progenitor of modern Slovene linguistics, Fran Ramovš. This portal, launched in 2014 as a successor to its predecessor Slovarske in besedilne zbirke ('Dictionaries and Corpora', the archived version of which is available at http:// bos.zrc-sazu.si), features searchable dictionaries and other linguistic resources, including Weiss 1998, Ivančič Kutin 2007, Gregorčič 2014, and the Slovene Linguistic Atlas, vol. 1 (Škofic et al. 2011). Separate from the institutional framework is the sophisticated web-based database of Carinthian Sn lexicon in Benko 2013. Further, the work of Montenegrin dialectologists (and philologists) can be followed in the journal Lingua Montenegrina (http://www.fcjk.me/ lingua-montenegrina), published by the Vojislav P. Nikčević Institute for Montenegrin Language and Linguistics in Cetinje, the first issue of which appeared in 2008. The electronic presentation of the journal is in whole PDFs per issue, which must be searched as such. In addition to the electronic resources noted above, important continuing series-of-record for dialectology include the Bosanskohercegovački dijalektološki zbornik (most recent issue: X, 2012) and Srpski dijalektološki zbornik (most recent issue: LXII, 2015). Another important vein of descriptive work resulting in thorough single-locale monographs continues from the Netherlands, following the framework of Ebeling-Kortlandt-Vermeer, e.g., Kalsbeek 1993 (Žminj, Čakavian), Houtzagers 1999 (Kajkavian exclaves in Hungary).

While field studies as such have proceeded at various paces, the emergence of new narratives reworking and reasserting the identities suppressed in the Yugoslav Serbian-Croatian binary reflect and/or underpin the contours of dialectological projects. Noteworthy in this regard are Peti-Stantić 2008which identifies regional ("dialectal") writing traditions that were woven into or inhibited in the process of standardization in the nineteenth century in the whole of the "BCSM" area (Bosnian, Croatian, Serbian, Montenegrin)Zajc 2006 with regard to the issue of delimiting Slovene and Croatian, as well as Nikčević 2009 on the individuality and periodization of Montenegrin as a language. An important and concise new overview of Montenegrin dialects, emphasizing their structural unity, is found in Čirgić 2017, which sketches out the historiography of research as well as notes and discusses the key structural points that distinguish them from the rest of the BCSM dialects.

With a focus on spoken dialects and their classification in the Croatian framework, important are the first two of three planned volumes on Croatian dialectology, Lisac 2003 (Štokavian and Torlak) and 2009 (Čakavian). In Lisac 2003 there is a shift in the criteria for national delineation of dialects from Yugoslav-era practice, which was based primarily on territorial unity-now the Torlak dialects in Serbia are viewed as Croatian (from a Croatian perspective) in those areas where the speakers identify as Roman Catholic; similarly, the Sandžak dialect in Serbia is seen as Bosnian (from a Bosnian Muslim per- 
spective) by virtue of the Islamic confession of its speakers (Begović and Begović-Ličina 2012). As Čirgić points out, however, the problem of designation and appropriation of identities with respect to territory, religion, and dialect in the former Yugoslav states is still in flux (2014).

Though there are as yet no signs of the appearance of dialect atlases for BCSM areas (with the exception of multilingual Istra, e.g., Filipi and Buršić-Giudici 1998, 2013; Cossutta 2005, 2006), new fundamental studies in the form of dialect monographs and dialect dictionaries are forming the basis for future synthetic and summative works. Of note here, for example, are the first monographic overview of Međimurje Kajkavian (Blažeka 2008) and a corresponding dialect dictionary (Blažeka and Rob 2014), a phraseological dictionary of Kajkavian (Marešić and Menac-Mihalić 2008), a first comprehensive dictionary of Bačka Croatian (Sekulić 2005), a first dictionary of the (400-year-old) archaic Croatian dialect enclave in W Slovakia (Takač 2004). The pace of development is evident in Sanja Vulić and Josip Lisac's foreword to Radulić 2002, "[...] in the last hundred years about sixty [Čakavian] dialect dictionaries have been published, of which a good third of them appeared in the last decade of the twentieth century" (3). Other notable contributions to dialect lexicography include Vuković 2001 (Selca on the island of Brač) and the amateur, but consistent and copious dictionary Roki-Fortunato 1997 (Vis), both Čakavian dialects. Analogously, Slovene dialects that had been on the path of standardization and/or which significantly diverge from the source material for the republican standard, are now enriching the literature; relatively few monographic descriptions of Slovene dialects were produced before 1989. Notable in this regard are Novak and Hajnšek-Holz's 2006 dictionary of Prekmurje Slovene; Pavel's previously unpublished "standard" grammar of Prekmurje Slovene (2013), the manuscript of which had been completed in 1942; the publication in dictionary form of a century-old set of dialect notes on the Središče dialect in Prlekija, in a border town with Croatia (Greenberg 1999); the first descriptive dialect of the highly divergent dialect of Resia (Steenwijk 1992), spoken in N Italy; and the first monograph-length presentation of the dialect of Gailtal/Zilja in Austria (Pronk 2009), which had initially been described briefly more than a century earlier.

Special mention should be made of the recent appearance of the remarkably thorough synthesis of the history of W SSl accentuation (modestly titled History of Croatian accentuation), Kapović 2015, which includes among its more than 1000 pages 16 color maps of the distribution of accentual phenomena produced in collaboration with the Russian linguist Miša Oslon. Finally, with regard to North American contributions we should note Greenberg 2000, which presents chronological cross cuts of the exceptionally reticulated Slovene dialect vowel systems, and Langston 2006, which offers the first holistic study of Čakavian accentuation systems. Special mention should be made 
of the problem-based treatment of the atypical Haloze dialect of Slovene in Lundberg 2013.

\section{Eastern South Slavic}

The term "East-South Slavic" (E-SSI) here is equivalent to "Balkan Slavic" and designates the Bulgarian, Macedonian, and Southeast Serbian (Prizren-Timok, "Torlak") linguistic continuum, which historically also includes Aegean Slavic dialects from eastern Albania through northern Greece and European Turkey, as well as Bulgarian diaspora dialects in Romania, Bessarabia, and Anatolia. For works prior to 2000 we cite only monographs not discussed in Alexander 2000 and 2006.

In Bulgaria since 2000, although the new series Trudove po bŭlgarska dialektologija $i$ istorija na bŭlgarski ezik has thus far produced only one monograph (Vakarelska-Čobanska 2002, a description of the SWBg Samokov dialect), the same period has seen a dramatic rise in nonseries monographs devoted to dialect dictionaries, published in a wide variety of venues, and representing the following regions:

1) Transitional NWBg, e.g.,Trŭn (A. Mladenov 2009);

2) SWBg, e.g., Iskrec [Svoge, north of Sofia] (Balkanski 2011), Samokov (Vakarelska-Čobanska 2005), Gorno Pole (Kotova, 1960-2000), Dobroslavci [Sofia] (Gŭlŭbov 2000, the most extensive Bulgarian dialect dictionary yet published);

3) NEBg, e.g., Erkeč (Keremedčieva et al. 2012);

4) Aegean dialects, e.g., Zarovo [Solun] (Vačeva-Xoteva and Keremedčieva 2000, a fundamental contribution to the study of an otherwise virtually extinct archaic diaspora dialect type), Southern Rhodope [Muslim Bulgarian dialects in northern Greece]/Drama-Sjar (Antonova-Vasileva and Mitrinov 2011).

Prior to 2000 we have a detailed artisan's lexicon of the CeBg Trojan region (Canov, Kovačev, and Totevski 1992) and a significant contribution to Rhodope lexicography (the series Stojčev 1965, 1970, 1983).

In addition to these major lexicographical works, we also now have descriptions of Čeč Rhodope (Srebranov 2007), CeBg Koprivštica (Keremedčieva 2007), and Bulgarian dialects in Bessarabia, such as Ternovka (Barbolova 2013, devoted to a rare Fakija diaspora dialect), as well as a large collection of Aegean Macedonian texts (Šklifov and Šklifova 2003). Long-awaited is the appearance of the first volume (over 1,000 pages) of the Ideografskija dialekten rečnik na bŭlgarskija ezik (Radeva et al. 2012), the first such onomasiological dictionary in 
the history of Slavic dialectology; decades in preparation, this major collective endeavor is based not only upon published sources but also draws from extensive fieldwork archives. In addition, toponymical dictionaries (usually categorized under "onomastics") have been published in large numbers (chiefly in Velikovo Tŭrnovo, including the Bŭlgarska Onomastika monograph series). A milestone in Bulgarian phonology is Žobov (2004), which provides many precise observations on the articulatory and acoustic properties of standard and dialectal Bulgarian, including 65 spectrographic illustrations. Another signal event is the publication of extensive selected works (some previously unpublished) of the eminent Bulgarian dialectologists Maksim Mladenov (Mladenov 2008, including 197 maps) and Todor Bojadžiev (Bojadžiev 2012). Finally, the pages of standard journals contain numerous contributions on a variety of topics by several scholars who wrote doctoral dissertations in the 1980s on Thracian and Moesian diaspora dialects, such as Canova 1985 [Mandŭr, Asia Minor], Čomonev 1986 [Avren, Carigrad], Dobreva 1986 [Gorno Čamurli, Dobrudža], Kitanova 1981 [Karaač, Odrin], Pavlova 1981 [Lozengrad], Vitanova 1985 [Enikjoj, Ksanti], as well as the morphologically archaic and phonologically idiosyncratic SE Rhodope Devesilovo dialect (Marinska 1991).

In the Republic of Macedonia, there are no journals devoted to dialectology as such, but the number of publications in this field in other venues (e.g., Posebni izdanija) has always been considerable. As in Bulgarian scholarship, in recent years Aegean dialects have drawn considerable attention, e.g., dictionaries for Lower Vardar and Solun (Peev 1999, which includes previously unpublished fieldnotes) and the SEMac Demir Hisar village of Čiflik (Davkova-Gjorgieva 2004), as well as dialect descriptions for the regions of Meglen (Bojkovska 2006, with audio CD), Enidže-Vardar (Karanfilovski 2013), and the village of Kula [Ser] (Labroska 2003). For other regions, we now have an extensive lexicon of the SWMac Demir Hisar dialect (Cvetkovski 2008) and dialect descriptions for EMac, e.g., Radoviš (Bojkovska 2003), Štip (Malenko 2012); for WMac, e.g., Kičevo (Labroska 2008), Karšijak (Cvetanovski 2004); for NMac, e.g., Polog (Labroska et al. 2012), Kriva Palanka (Stoevska-Denčeva 2004); and for the WMac periphery, e.g, Mala Prespa (Cvetanovski 2010) and Ohrid (Markovik' 2007, also of value for its comparative description of the Farşeroţi Aromanian dialect). Kiš 1996 (with 20 detailed maps) is a unique and richly documented etymological study of the Macedonian dialect lexicon for 87 varieties of flora (trees, plants, berries, and grains).

An entirely new and significant development in E-SSl dialectology of recent years is the creation of three electronic databases, two of which are supported by international cooperation. All three provide interactive dialect maps with village points linked to audio files of field recordings of dialect speech, although the number of available audio files varies. The first (and largest) of these databases is Alexander and Zhobov 2011-2016, a joint Bulgarian-American project, which offers 181 texts excerpted from material recorded in 68 
different Bulgarian villages. The text-plus-audio selection (culled from an overall corpus of ca. 200 hours) includes inter alia material from villages with particularly interesting vocalism, such as Tixomir (E Rhodope), Golica and Kozičino (Erkeč), and Trŭnčovica (N Pavlikjan). The second such database is O. Mladenova and D. Mladenova 2001-2013, a joint Bulgarian-Canadian project, designed as a supplement to Maksim Mladenov's 1993 monumental work on Bulgarian dialects in Romania (the audio files are based mainly on Mladenov's field recordings from 1969-1972). The site provides detailed descriptions of dialect phonology and classification for 38 villages. Thus far, transcription and audio are complete for several of the westernmost villages. The third project, Markovik' (2012), is devoted to Macedonian dialects. Based at the Istražuvački centar za arealna lingvistika "Božidar Vidoeski" in Skopje, the site at present provides preliminary sample digitized files (3-4 minutes in length) of tape recordings from Vidoeski's dialect archive for more than 15 dialect points, although transcriptions for the recordings are not yet available. The site also includes links to dialect texts for approximately 300 villages (mainly drawn from Vidoeski 2000, but including extensive material from the Enidže Vardar dialect).

Another product of Bulgarian-North American collaboration (including fieldwork conducted by two joint teams of researchers in the 1990s in Bulgaria) is Alexander and Zhobov (2004), an early example of open-access scholarship in Slavic linguistics, devoted chiefly to the lexicon (see in particular Delčeva 2004), phonology, and prosody of Bulgarian dialects, in particular the Erkeč dialect.

In Russia and Germany, the multilateral MDABJ series (Malyj dialektologičeskij atlas balkanskix jazykov, see Sobolev 2003a, 2003b, 2005, 2006, 2009, 2013) provides useful information on the comparative lexicon of the Balkan Sprachbund, including material from four E-SSl dialects (Peštani [SWMac], Gega [Pirin], Gela [CeRhodope], Ravna [Mizija]), although even more important for Bulgarian dialectology specifically is the somewhat earlier monograph on the CeRhodope dialect of Gela [Široka Lŭka] (Sobolev 2001). In Ukraine, a comparatively new series Bŭlgarskite govori v Ukrajna (published in Bulgarian in Odessa) includes dialect descriptions for Červonoarmejskoe (Barbolova 1999) and Kalčevo (Topalova 2009). In addition, some volumes of the journal Issledovanija po slavjanskoj dialektologii (1993-present, 17 vols.) contain significant E-SSl material, e.g., vol. 2 (Korten-Kirjutnja phonology, Kalnyn' and Popova 1993), as well as various smaller contributions to the ethnographic lexicon by Klepikova, Plotnikova, Sedakova, and Uzeneva (see vols. 2, 7, 10, 13).

Of recent contributions by Western scholars, probably the most significant is Steinke and Ylli 2007, 2008, 2010, three volumes (each with audio CD) dedicated to Macedonian dialects spoken in Albania (e.g., Prespa-Vrnik-Boboštica, Golo Brdo, Gora; for a review, see Friedman 2011). Comparatively exotic Aegean dialects are also described in Šmiger 1998 (Nestram in southern 
Kostur) and Adamou 2006 (Ajvajti/Ajvatovo [a Solun dialect], last described by Małecki in 1934 and currently on the verge of extinction).

Extensive E-SSI dialect material and linguistic geography have also been put to productive use by historical linguists, e.g., notably O. Mladenova 2007 (on the development of the morphosemantic category of definiteness in Bulgarian, including Macedonian, chiefly pp. 297-433, with data from the unpublished archives of Mladenov) and Mǔžlekova 1990, 1994 (on the lexical connections between OCS/OBg and modern Bulgarian dialects), as well as by ethnolinguists, e.g., D. Mladenova 2006 (an award-winning study of folk astronomy), 2010, 2016 (a linguistic and cultural history of terms for 'tomato' and 'eggplant' in Bulgarian and Macedonian), and Plotnikova 2004 (on the folk calendar, family customs, and mythology).

The field of Torlak dialectology has been enriched by several major dialect dictionaries, e.g., Timok (Dinić 1988, 1990, 1992), Pirot (Zlatković 1988, 1989, 1990), as well as the more recent summative work Dinić 2008 (Timok).

\section{East Slavic}

Despite the significant political and socio-economic transformations that accompanied the collapse of the USSR in 1991, research in the field of ESI dialectology over the last quarter century, both within and beyond the borders of the Russian Federation, Ukraine, and the Republic of Belarus, has to a considerable extent continued within the theoretical and institutional frameworks established in the Soviet period. While conditions vary to some extent from country to country as well as across different regions within their borders, a number of common trends can be observed that are directly relevant to the study of dialect variation and change throughout the ESl continuum. Above all, much of the ESl speech territory has experienced, particularly since WWII, fairly rapid erosion of rural dialects as a result of Soviet-era policies of forced collectivization, as well as ongoing processes of rural-urban migration and rural depopulation. These processes, as well as the evacuation of significant numbers of rural residents from the Chernobyl zone in NC Ukraine and particularly SE Belarus, have made the thorough documentation of the most archaic ESl dialect phenomena a particularly urgent task for dialectologists. At the same time, ongoing processes of dialect contact and dialect-standard convergence (de-dialectization) have created new opportunities for sociolinguistically-informed studies of dialect variation and change. ${ }^{4}$

The expanded role of the 'titular' languages in Ukraine and-to a much more limited extent-in Belarus since independence in 1991 has focused the

4 It should be noted that one of the earliest sociolinguistic studies in Sl dialectology was carried out by a Russian linguist, N. M. Karinskij (1936), who investigated social variation in the $\mathrm{C} R \mathrm{Ru}$ dialect of Vanilovo in both real and apparent time. 
attention of many linguists in those countries on their respective standard languages rather than nonstandard varieties, although dialect material continues to be a source for lexical enrichment for both standard Uk and standard Br. In addition, the emergence of new ESl literary microlanguages with varying degrees of official recognition, including Rusyn in the Prešov region of Slovakia, Lemko in Poland, and potentially, svoja mova or Podlachian in Poland, has added an ideological dimension to dialectological research on the varieties in question.

In the case of $\mathrm{Br}$ and to some extent Uk (particularly in the $\mathrm{E}$ and $\mathrm{S}$ regions of the Uk speech territory), the process of de-dialectization has involved primarily convergence not toward the endogenous $\mathrm{Br}$ or Uk standard languages, but rather the exogenous standard Ru language. Until recently, the study of the resulting semiurban and in some cases, rural mixed varieties, popularly known as suržyk in Ukraine and trasjanka in Belarus, was considered outside the scope of dialectology, although this has begun to change as the theoretical concerns and methods of variationist sociolinguistics have gained greater currency among ESI dialectologists.

The first two decades after the Soviet collapse saw the completion of a number of large-scale dialect atlas projects covering nearly all of the original ESl speech territory. A noteworthy achievement in Ru dialect cartography was the publication of the Russian Dialectological Atlas (Dialektologičeskij atlas russkogo jazyka [DARJa], Avanesov and Bromlej 1986-2005: vol. 1, phonetics (1986); vol. 2, morphology (1989); vol. 3, syntax and lexis (1996), with separate editions of large-scale maps for lexis (2002) and syntax and lexis (2005)). Based on data collected from the late 1940s to the mid-1960s, the Atlas includes nearly all of the pre-16th century Ru speech territory (the 'primary' Ru dialects or govory pervičnogo formirovanija), with the exception of the $\mathrm{N} \mathrm{Ru}$ dialects of the Arkhangelsk region, which was colonized by Novgorod as early as the 13th century, along with dialects in W and S Russia that were classified by the Moscow Dialect Commission in 1915 as Br (W Smolensk, Roslavl' and Staro$\mathrm{dub}$ ) and Uk (portions of the S Kursk and Voronezh regions).

An interesting and quite unique byproduct of the work on the DARJa is Bukrinskaja et al.'s Dialect Atlas for Schools (1994), which was designed to introduce the fundamentals of dialectology and linguistic geography to a school-age audience and to promote awareness of and appreciation for Russia's dialect diversity (a truly remarkable development, given the strength of the standard language ideology in Russia and the Ru-speaking world).

A planned lexical atlas of Ru dialects has yet to appear, although some indication of its potential scope is provided by the series of working publications under the title Leksičeskij atlas russkix narodnyx govorov: materialy $i$ issledovanija (LARNG) (Gerd, 1992- ). Published by the Linguistics Research Institute of the Russian Academy of Sciences (St. Petersburg), LARNG contains valuable 
materials on dialect lexis, semantics, the structure of specific thematic lexical groups, word formation, dialect phraseology and onomastics.

Over the last 25 years Ru dialectologists have also continued to map dialect phenomena beyond the 'primary' Ru dialect area (i.e., areas of post-16th century colonization), including the Volga region and Siberia. Atlases focusing on 'secondary' Ru dialects (govory vtoričnogo formirovanija) include, among others, Myznikov's (2005) volume on the Ru dialects of the C Volga region (Chuvashia and Mari El) and Zdobnova's (2000) atlas of Ru dialects of Bashkortostan.

The last quarter century has also seen the completion of the three-volume Atlas of the Ukrainian Language (Atlas ukrajins'koji movy [AUM], Matvijas et al, 1984-2001). The atlas is, rather inconveniently, divided into volumes by region, the first volume covering the $C$ dialects (Polesia, the Middle Dnieper region and neighboring regions), the second, the $\mathrm{W}$ dialects (Volhynia, the Upper Dniestr region, Transcarpathia and adjoining regions), and the third (published in 2001) consisting of three parts, the first two featuring "secondary" Uk dialects, i.e., the dialects of Sloboda Ukraine and the Donetsk region in part 1, the Lower Dnieper basin, the Black Sea coast and neighboring regions in part 2, and part 3 with 53 comprehensive maps covering the entire territory of Ukraine.

In addition to the AUM, a number of Uk regional dialect atlases have also appeared since Ukraine gained independence in 1991, including Martynova's (2003) phonological atlas of the C Uk dialects of the mid-Dnieper region and Herman's (1994-98) dialect atlas of N Bukovyna. The two portions of the Uk speech territory that have received the greatest attention from Uk dialect cartographers, due to their archaic character and dialectal diversity, are Uk Polesia and the Carpathian region. Uk Polesia is represented by, among other works, Nykončuk's (1994) lexical atlas of Right-bank Polesia, Omelkovec"s (2003) atlas of W Polesian names for medicinal herbs, and Kurylenko's (2004) atlas of Polesian animal husbandry terminology. The Carpathian region is represented by Rieger's (1996) lexical atlas of the Hutsul dialects and dialect atlases of Uk (Rusyn) dialects of E Slovakia (Hanudel' 1981-2001 and Latta 1991).

Since the publication of the comprehensive Br dialect atlas in 1963 (DABM, the first complete atlas for any of the ESl languages; Avanesaŭ, Krapiva, and Mackevič 1963), Br dialectologists have continued to be at the forefront of work in ESl dialect cartography. The first Br dialect atlas to appear after the break-up of the Soviet Union was the five-volume lexical atlas (Biryla and Mackevič 1993-1998), based on data collected in 142 locations, with 1846 maps. The volumes include the plant and animal world (vol. 1, 1993), agriculture (vol. 2, 1994), people (vol. 3, 1996), everyday life (vol 4., 1997), and semantics, word formation, and word stress (vol. 5, 1998). As for regional dialect atlases, much of the activity in the last 25 years has focused on SW Belarus, including 
both the West Polesian dialects (considered by many Uk dialectologists an integral part of the Uk speech territory), as well as adjacent transitional dialects. These works include Bosak and Bosak's (2006) lexical atlas of the dialects of the Pružany district, Čarnjakevič's (2009) atlas of the dialects of the NE Brest region (encompassing both SW Br dialects and the northernmost transitional West Polesian dialects, from the town of Slonim in the north to the Jasel'da river in the south, with 365 maps for 90 phonetic, 74 morphological, and 180 lexical variants, along with 20 isogloss maps), Veštart et al.'s (2008) lexical atlas of Br Pripyat Polesia, and Levancevič's comprehensive four-volume atlas of the dialects of the Byaroza district (vols. 1 and 2, phonetics [1993]; vol. 3, morphology [1994]; vol. 4, lexicon [2001]).

Another significant achievement in ESl dialect cartography of the last quarter century is a multi-volume atlas of ESl dialects of the Białystok region (NE Poland) compiled by a group of Polish researchers (Glinka et al, 19802012), covering typologically Br-like dialects in the north (spoken mainly by Roman Catholics who self-identify as Poles) to transitional and Uk-like dialects in the south (whose speakers, nearly all Eastern Orthodox, tend to self-identify as Br rather than Uk).

Based on an idea first suggested by R. I. Avanesov in the 1960s, beginning in the late 1980s a team of dialectologists from the Russian Language Institute of the USSR Academy of Sciences, the Institute of the Ukrainian Language of the Ukrainian SSR Academy of Sciences, and the Jakub Kolas Institute of Linguistics of the Belarusian SSR Academy of Sciences began work on a compilation atlas of ESl isoglosses that would include data from all three national dialect atlases and other regional dialect atlases. According to Avanesov's original conception, further elaborated in 1987-1990 by his colleague S. V. Bromlej, the proposed atlas was to supersede the Moscow Dialectological Commission's 1915 map of "the Russian language in Europe." Despite the disruption of institutional ties between the three ESI national academies after the Soviet collapse, the first volume resulting from this project, Vostočnoslavjanskie izoglossy (VSI) (Popova 1995), published with funding from the Soros Foundation, appeared four years later. Three subsequent volumes of VSI appeared in 1998, 2000, and 2006. The maps in these publications, unfortunately not all of the best quality, include a variety of phonological, prosodic, morphological, syntactic, and lexical isoglosses. The focus of this atlas is primarily historical, the aim being to reconstruct early dialectal divisions within ESl.

As in the West and South Slavic countries, dialect lexicography has continued to be a major focus for ESl dialectologists. The Slovar' russkix narodnyx govorov (Filin and Sorokaletov 1965-), which began publication over 50 years ago, is now available online through vol. 46 (Tyčak-Užolja, 2013) on the site of the Linguistic Research Institute of the Russian Academy of Sciences (https:// iling.spb.ru/vocabula/ srng/srng.html). This massive, now nearly complete dialect dictionary includes lexis representing nearly all thematic groups related to 
traditional Ru peasant life, making it an invaluable resource not only for linguistic, but also interdisciplinary historical and ethnographic research.

As noted by Alexander (2006), a number of Ru regional dialect dictionaries have also appeared since the end of the Soviet period. Particularly worthy of note are a five-volume thematic dictionary of the dialects of the Tver region (Kirillova and Novikova 2002-2006), a dictionary of dialects of the Ru North (Vologda and Arkhangelsk regions) (Matveev 2001-), as well as dictionaries of the dialects of the Kostroma region (Gancovskaja 2015) and the Arkhangelsk region (Gecova and Nefedova 1980-), of which the most recent volume (no. 16, Zagavasit'-Zajčiško) appeared in 2015 (all 16 volumes are available online on the website of the Dialectology Section of the Department of Russian at Moscow State University: http://www.philol.msu.ru/ dialectology/dictionary/). S Ru dialect lexis is featured in a dialect dictionary of the Kursk region (Pimenova 2004-; most recent volume, Kaba-Kyčka, 2015).

As in the case of dialect atlases, over the last 25 years there has been significant progress in the dialect lexicography of areas of later Ru settlement and colonization. Recent works covering so-called "secondary dialects" include dictionaries of $\mathrm{Ru}$ dialects of Mordovia (Mixaleva 2013), Chuvashia (Kolesnikova 2003), the S Kama River river region (Podjukov 2010-2012), and Bashkortostan (Zdobnova 2008), as well as a dictionary of old-settler dialects of Baikal Siberia (Afanas'eva-Medvedeva 2007-), and an etymological dictionary of borrowings from Uralic, Altaic, and Paleoasiatic languages in the Ru dialects of Siberia (Anikin 1997).

While for the most part work in Ru dialect lexicography continues to be carried out by professional linguists, in the post-Soviet period these efforts have been occasionally supplemented by the work of individuals and groups associated with language and cultural revival movements. We may include in this category the dictionary of North Ru Pomor dialect (pomor'ska govorja) of the White Sea littoral and neighboring regions (Moseev 2005), published by Ivan Moseev, an Arkhangelsk journalist, former director of the Scientific and Educational Center The Pomor'e Institute of Indigenous and Minority Ethnic Groups (Pomorskij institut korennyx $i$ maločislennyx narodov) at the Lomonosov Northern (Arctic) Federal University, and activist in the Pomor revival movement. His dictionary of the Pomor dialect (provocatively termed the "Pomor language") includes basic information on Pomor phonetics as well as a basic grammar, and is explicitly intended to assist linguistic revitalization efforts. ${ }^{5}$

\footnotetext{
5 In the fall of 2012 Moseev was accused of treason by the Russian Federal Security Service (FSB) due to his work with Norwegian NGOs promoting cross-border cultural exchange, and in the spring of 2013 found guilty of "extremism," fined, fired from his university post in Arkhangelsk, and placed on Russia's official list of "terrorists and extremists."
} 
A number of important works in Uk dialect lexicography have also appeared since 1991. As in the case of dialect cartography, most of these recent publications focus on the dialects of W Ukraine, in particular the N Uk dialects of West and C Polesia and the SW Uk dialects (in particular the Carpathian region and Transcarpathia). Representative lexicographical works focusing on these regions include a two-volume West Polesian dialect dictionary (Arkušyn 2000), a dictionary of Volhynian folk geographical terminology (Danyljuk 1997), a regional dictionary for the Upper Dniestr dialects of the Lviv, Ternopil, and Ivano-Frankivsk regions (Šylo 2008), a dialect dictionary of the C Bojko region (Matvijiv 2013), and a dictionary of dialect lexis from the village of Hrabovec' near Stryj (Lviv oblast') (Drul' 2006). The distinctive SW Uk Hutsul dialect lexicon is represented in a number of recent lexicographical works, including Janów 2001 and Xobzej 2013, as well as an ethnolinguistic dictionary of Hutsul folk mythology (Xobzej 2002). Transcarpathian Uk dialects are the focus of a number of recent lexicographical works, including Nikolaev and Tolstaja's 2001 dictionary of the dialect of the village of Torun', including a grammar outline and dialect texts (available online at: http://ablaut. narod.ru/torun/torun.htm), and a dialect dictionary for the village of Sokyrnytsia near Khust (Sabadoš 2008). Lemko dialects in Slovakia and S Poland are represented by, among other lexicographical works, a Lemko phraseological dictionary (Stupins'ka and Bitkivs'ka 2012 and a dictionary of the dialect of Tylicz in Poland's Nowy Sącz district (Turčyn 2011)). Dialect lexis of the SW Uk dialects of Podolia is featured in a recent dictionary (Kroxmaljuk 2015) of the dialects of the village of Senderivka and neighboring communities in the vicinity of Mohiliv-Podil's'kyj.

The SE Uk dialects, formed as a result of later (post-16th century) colonization of the Pontic Steppe, are less well represented in the lexicographical literature, although in recent years a number of dialect dictionaries representing this portion of the Uk speech territory have also appeared. These newer works include materials for a dialect dictionary of C Sloboda Ukraine (the Kharkiv region, Saharovs'kyj 2011-2013) and a phraseological dictionary of the dialects of the Donbas region (Užčenko 2013), including both E Sloboda dialects of the N Luhansk oblast and the steppe dialects of the S Luhansk and Donetsk oblasts. Needless to say, the ongoing armed conflict in the Donbas, as well as the anti-Uk position of the local authorities in the self-proclaimed Luhansk and Donetsk People's Republics, makes any further progress in the study of the endangered Uk dialects of this region highly unlikely for the foreseeable future.

The study of SE Uk dialect lexis east of the post-1991 Ukrainian-Russian state border has also progressed since the collapse of the USSR. Two recent lexicographical works worthy of mention are a dictionary of the E Sloboda Uk dialects in the S part of Russia's Voronehz oblast' (Avdeeva 2008-) and ma- 
terials for a dictionary of the Kuban' dialects (the so-called kuban'ska balačka, spoken by descendants of the exiled Zaporozhian Cossacks, Borisova 2005).

Since the break-up of the Soviet Union a number of important works on $\mathrm{Br}$ dialect lexicography and toponymy have also appeared. The NE Br dialects are represented by a Vitsebsk regional dictionary (Zlobin et al. 2012-2014), a two-volume dictionary of the dialects of the Syanno region SW of Vitebsk (Bun'ko 2015), and a second volume of materials for a regional dictionary of the Mahilyow region (Ababurka et al. 2005), the first volume of which appeared as long ago as 1981, as well as a dictionary of Mahilyow region dialect microtoponyms (Klimuc' et al. 2004). The NW segment of the SW Br dialect area is represented by, among other works, a regional dialect dictionary for the Hrodna region (Danilovič and Scjacko 1999), which includes lexis not previously recorded in other regional dictionaries, including the 5-volume dictionary of the dialects of NW Belarus and its border regions (Mackevič et al. 1979-1986), as well as a 4000-word regional dialect dictionary and phraseological dictionary of the Kosava region near Ivatsevichy, compiled not by a professional dialectologist, but by a talented amateur, a local teacher of $\mathrm{Br}$ (Zajka 2011, 2014).

Recent works on dialect lexicography and toponymy representing the SE portion of the SW Br dialects (part of the Mazyr dialect group) include a dialect dictionary for the Lelchytsy district (Kučuk and Maljuk 2000), the first systematic collection of dialect lexis from this part of E Polesia, and a dictionary of microtoponyms of the Mazyr region (Ivanova 2008).

The transitional Br-Uk dialects of West Polesia and Podlasie (NE Poland) are also reflected in a number of works on dialect lexicography and toponymy that have appeared since 1991. Dialect lexis of Br Pripyat Polesia is featured in Veštart et al. 2008, while the transitional dialects of Podlasie are represented in such publications as Wróblewski 2008, a dictionary of the dialect of the village of Chraboły and the Bielsk suburb of Studziwody, and Kondratiuk 2014, a dictionary of dialect toponyms of the Białystok region.

There are at present a number of series publications featuring research on ESI dialectology, some of them already well established and others of much more recent vintage. Since 1992 the Institute of Slavic Studies of the Russian Academy of Sciences has published Issledovanija po slavjanskoj dialektologii (http://www.inslav.ru/resursy/elektronnaya-biblioteka/275-isd), including two volumes devoted exclusively to research on ESl dialects, vol. 2 (1992) on Carpatho-Ukrainian dialects, and vol. 8 (2002) on ESl linguistic geography in its broader $\mathrm{Sl}$ context, while ESl material is well represented in other volumes, including the most recent, vol. 17 (2015), on new trends in Sl dialectology in the 21st century. The V. V. Vinogradov Russian Language Institute of the Russian Academy of Sciences publishes a series featuring new research in Ru dialectology, Materialy i issledovanija po russkoj dialektologii (2002-), along with other serial publications in $\mathrm{Ru}$ linguistics that include dialectology within 
their purview, the journal Russkij jazyk v naučnom osveščenii (2001-) (available online at: http://www.ruslang.ru/ agens.php?id=rjano) and the new series, Trudy instituta russkogo jazyka im. V. V. Vinogradova (2014-), the latter including articles not only on $\mathrm{Ru}$, but also $\mathrm{Uk}$ and $\mathrm{Br}$ dialectology and linguistic geography.

Research on Uk dialectology is featured in two major serial publications, Ukrajins'kyj dialektolohičnyj zbirnyk (1997-), published by the Ukrainian Language Institute of the Academy of Sciences of Ukraine, and Dialektolohični studiji (2003-), published by the Lviv-based Kryp'jakevyč Institute of Ukrainian Studies. Research in Uk anthropological linguistics and ethnolinguistics is featured in the new series Etnolinhvistyčni studiji (2007-), a joint publication by the Ukrainian Language Institute of the Academy of Sciences and the Center for Ethnolinguistic Research at Ivan Franko State University in Zhytomyr.

$\mathrm{Br}$ dialectology is represented in two major series publications by the Jakub Kolas and Janka Kupala Institute of Language and Literature of the Belarusian Academy of Sciences, Belaruskaja linhvistyka (1972-) (http://nasb.gov. by/bel/ publications/ belling/index.php), and Belaruskaja dyjalektalohija (materyjaly $i$ dasledavanni) (2010-).

Dialectological material is not currently one of the strengths of existing ESl online corpora, although there are some promising signs for future expansion in this area. The Russian National Corpus (Nacional'nyj korpus russkogo jazyka) contains a searchable dialect subcorpus (http://www.ruscorpora.ru/ search-dialect.html) representing both primary and secondary dialect areas from European Russia to the Transbaikal region. The texts in the dialect subcorpus are recorded in a near-standard orthography, with word stress marked inconsistently, making it not particularly useful for the study of phonetic variation. The relatively small size of the dialect subcorpus (currently less than 200,000 tokens) is a serious limitation, although it is searchable according to a range of grammatical features including part of speech, case, number, gender, animacy, voice, mood, aspect, tense, person, transitivity, declension and conjugation type, and derivational morphology (including both narrowly dialectal morphemes and those shared with the standard language). Still very much a work in progress, the dialect subcorpus of the RNC is being constantly expanded, and there are plans to create a multimedia supplement with audio and video recordings.

$\mathrm{N} \mathrm{Ru}$ dialects of the Arkhangelsk region are the focus of another searchable online dialect corpus, the Ustja River Basin Corpus (http://www.slavist.de/ Pushkino/login.php), consisting of dialect texts collected on a series of expeditions in 2013-2016 by an international team of researchers from the School of Linguistics at the Higher School of Economics in Moscow and the Slavic Institute of Bern University, Switzerland. As in the case of the RNC dialect subcorpus, the interviews were transcribed into near-standard orthography. The lack of phonetic detail in the transcription is compensated for by a web- 
based interface that provides access to the original sound recordings at the level of individual utterances. An innovative aspect of the interviews conducted for this corpus is that the researchers sought to document synchronic intra-community variation, reflecting ongoing processes of dialect attrition and the emergence of new regional mesolectal varieties as a result of convergence toward standard Ru.

NW Ru dialects of the Pskov region are represented in the multilingual TriMCo dialect corpus (http://www.trimco.uni-mainz.de) representing the Ba-Sl contact zone from NW Russia, N and NW Belarus, SE Lithuania and E Latvia (Latgalia). This project, headed by Björn Wiemer (University of Mainz, Germany), seeks to explore areal phenomena in the Ba-Sl contact zone through a combination of methods and approaches including linguistic typology, areal and contact linguistics, dialect geography, and corpus linguistics.

The Korpus ukrajins'koji movy (http://www.mova.info/corpus.aspx?11=209), created by researchers at the Department of the Modern Ukrainian Language at the Institute of Philology of the Ukrainian Academy of Sciences, includes a small (currently only 79,316 tokens) dialect corpus, consisting of texts taken from published oral folklore collections. As in the case of the Ru dialect subcorpus, the materials are rendered in a more or less standard orthography. In coming years, the Institute plans to expand the dialectological component of the Uk corpus with Uk regional and diasporic subcorpora. Unlike the RNC dialect subcorpus, the search options in the Uk corpus are limited to lexemes and specific word forms.

For $\mathrm{Br}$, there is currently only a pilot version of a national corpus (Belaruski N-korpus) (http://bnkorpus.info/about.html), including oral folkloric texts (fairy tales, ballads, etc.) representing non-standard regional varieties. The search options are limited to part of speech, although a reverse dictionary is also included. Br dialects from the Ba-Sl contact zone of E Lithuania, NW Belarus, and E Latvia (Latgalia) are also represented in the aforementioned multi-lingual TriMCo corpus (https://www.trimco.uni-mainz.de/home/). Some of the $\mathrm{Br}$ data from this corpus, accounting for some $40 \%$ of the total, are discussed in Seržant and Wiemer (2014).

An interesting, if somewhat unconventional, online resource for dialect lexicography of the transitional Br-Uk dialects of Podlasie in NE Poland is the searchable database for dialect lexis of the village of Kuraszewo near Bielsk (http://svoja.org/gramatyka/slovnik-jana-petrucuka-baza-danych\#dict), included on the site svoja.org. This site, created by the journalist Jan Maksymiuk along with other local language activists, is dedicated to the promotion and codification of the ESl dialects (termed pudlaśka mova or Podlachian by Maksymiuk) of the area between Bielsk and Hajnówka.

The widespread phenomenon of mixed Br-Ru speech is the focus of another new online corpus, the Oldenburg Corpus of Mixed Belarusian-Russian Speech (Oldenburger Korpus zur weißrussisch-russischen gemischten 
Rede) based on recordings made in smaller towns in different regions of Belarus (https://www.uni.oldenburg.de/en/slavistik/forschung/sprachwissenschaft/ schwerpunkt-mischvarietaeten/oc-brms/). The Oldenburg corpus consists of two subcorpora: a family corpus, with transcribed recordings of informal family conversations, and an interview corpus, with transcribed sociolinguistic interviews dealing with a variety of topics. The family corpus consists of approximately 212,000 word forms or 39,000 utterances in 444 conversations of various lengths while the interview corpus, from 54 structured interviews, includes approximately 170,000 word forms in 23,000 utterances. The family and interview subcorpora represent mixed $\mathrm{Br}-\mathrm{Ru}$ speech with a variety of different dialectal substrata: SW Br (recordings of speakers in Baranavichy and Slonim), C Br (Smarhon' and Rahačoŭ) and NE Br (Šarkoǔščyna, and Xocimsk). The corpus is a product of a large, multi-year project headed by Gerd Hentschel (University of Oldenburg, Germany) focusing on the comparative study of mixed Br-Ru and Uk-Ru speech, funded by the Volkswagen Foundation. Some of the preliminary results of this project are presented in Hentschel, Taranenko, and Zaprudski (2014), as well as in a series of recent articles by Hentschel and his students.

In addition to online searchable corpora and databases, a number of other online resources for ESI dialectology have appeared over the last decade. One of the most ambitious of these is the online Information Center for Russian Dialectology, created by the Russian Language Institute of the Russian Academy of Sciences (http://www.ruslang.ru/ agens.php?id=rus_dialectology). According to its website, the Information Center's mission is to disseminate information about $\mathrm{Ru}$ research units engaged in dialectological research and coordinate their efforts, share information on dialectological expeditions and the organization of student dialectological fieldwork, as well as publish reports on the results of new fieldwork, compile bibliographies of dictionaries, dissertations, monographs, and articles on $\mathrm{Ru}$ dialectology published since 1985, to help fill regional lacunae in dialect lexical and onomastic dictionaries and atlases, create and expand a library of electronic resources on Ru dialectology, and maintain contacts with foreign research units and organizations engaged in research in $\mathrm{Ru}$ and Sl dialectology. The Information Center's library of electronic resources (http://www.ruslang.ru/?id=dialectolog_centers_links) currently includes links to scanned pdf versions of a wide variety of works on Ru dialectology from the 19th century to the present day, including dialect dictionaries, monographs, and articles.

A useful new online resource for Br dialectology is the Belaruski dyjalektny leksihrafičny fond (http://philology.by/page/fund) on the site Philology.by, created by a group of linguists from the Department of General and Slavic Linguistics at Belarusian State University, the Institute of Language and Literature of the Belarusian Academy of Sciences, and Belarusian State Linguistic University. In addition to scanned pdf versions of dialect dictionaries and other works on 
Br dialect lexicography published since the 1960s, this site also includes links to scanned versions of dialect atlases, including the DABM and LABNH.

\section{References}

Ababurka, Mikalaj V., et al. (2005) Materyjaly da ablasnoha sloŭnika Mahilëŭščyny. Vol. 2. Mogilev: MDU imja A. A. Kuljašova.

Adamou, Evangelia. (2006) Le nashta: Description d'un parler slave de Grèce en voie de disparition. Munich: Lincom Europa. [Languages of the World/Materials, 456.]

Afanas'eva-Medvedeva, Galina V. (2007-) Slovar' govorov russkix starožilov Bajkal'skoj Sibiri v dvadcati tomax. Irkutsk: Irkutskaja oblastnaja tip.

ALE = Atlas Linguarum Europae. Available at: http://www.lingv.ro/index.php?option=com_content\&view=article\&id=81\&ltemid=109.

Alexander, Ronelle. (2000) In honor of diversity: The linguistic resources of the Balkans. Columbus, Ohio: Ohio State University, Dept. of Slavic and East European Languages and Literatures. [Annual Kenneth Naylor Memorial Lecture, 2]

. (2006) "Dialectology". Glossos 8. Available at: http://slaviccenters.duke. edu/uploads/media_items/8alexander.original.pdf

Alexander, Ronelle and Vladimir Zhobov, eds. (2004) Revitalizing Bulgarian dialectology. UCIAS. Available at: http://escholarship.org/uc/item/9hc6x8hp.

Alexander, Ronelle and Vladimir Zhobov. (2011-2016) Bulgarian dialectology as living tradition. Available at: http://bulgariandialectology.org.

Anikin, Aleksandr E. (1997) Ètimologičeskij slovar' russkix dialektov Sibiri: Zaimstvovanija iz ural'skix, altajskix i paleoaziatskix jazykov. Novosibirsk: Nauka.

Antonova-Vasileva, Lučija and Georgi Mitrinov. (2011) Rečnik na bŭlgarskite govori v južnite Rodopi, Dramsko i Sjarsko. Sofia: Bŭlgarska akademija na naukite. Institut za bŭlgarski ezik "Professor Ljubomir Andrejčin".

Arkušyn, Hryhorij L. (2000) Slovnyk zaxidnopolis'kyx hovirok: U dvox tomax. Lutsk: Veža.

Arkušyn, Hryhorij L. (2008) Atlas zaxidnopolis'kyx faunonomeniv. Lutsk: Veža. Avanesov, Ruben I. and Sof'ja V. Bromlej, eds. (1986-2005) Dialektologičeskij atlas russkogo jazyka: Centr evropejskoj časti SSSR. 3 vols. Moscow: Nauka.

Avanesaŭ (Avanesov), Ruben I., Kandrat K. Krapiva and Juzefa F. Mackevič, eds. (1963) Dyjalektalahičny atlas belaruskaj movy. 2 vols. Minsk: Vydavectva Akadèmii navuk BSSR. Scanned version available at: http://philology.by/ page/dabm.

Avdeeva, Marija T. (2008-) Slovar' ukrainskix govorov Voronežskoj oblasti. : IPC VGU.

Balhar, Jan and Pavel Jančák, eds. (1992-2011) Český jazykový atlas. Prague: Academia. Available at: http://cja.ujc.cas.cz/. 
Balkanski, Bojan. (2011) Rečnik na govora na s. Iskrec, Sofijsko. Sofia: Izdatelstvoto Simolini.

Barbolova, Zoja. (1999) Osobenosti na bŭlgarskija govor v s. Červonoarmejskoe (Kubej), Besarabija. Odessa: Izd. Astroprint. [Bülgarskite govori v Ukrajna, 2]

-. (2013) Bŭlgarskijat govor v Nikolaevskata Ternovka (Ukrajna). Sofia: Simeks-print.

Bartmiński, Jerzy, ed. (1996-2012) Stownik stereotypów i symboli ludowych. Lublin: Uniwersytet Marii Curie-Skłodowskiej.

Begović, Džavid and Šefka Begović-Ličina. (2012) Sandžački rječnik. Prilog leksikografiji bosanskog jezika. Sarajevo: Autori.

Benko, Anja. (2013) Narečna bera. Koroška narečja-materinščina vsakega Korošca in vsake Korošice. Available at: http://www.narecna-bera.si/.

Biryla, Mikalaj V. and Juzefa F. Mackevič, eds. (1993-1998) Leksičny atlas belaruskix narodnyx havorak u pjaci tamax. 5 vols. Minsk: Fond fundamental'nyx dasledvannjaŭ Respubliki Belarus'.

Blažeka, Đuro. (2008) Međimurski dijalekt. Hrvatski kajkavski govori Međimurja. Čakovec: Matica hrvatska.

Blažeka, Đuro, and Grozdana Rob. (2014) Rječnik Murskog Središća. Zagreb: Učiteljski fakultet Sveučilišta u Zagrebu.

Bojadžiev, Todor. (2012) Knižoven ezik i dialekti. Izbrani trudove. Sofia: Universtitetsko izdanie "Sv. Kliment Oxridski".

Bojkovska, Stojka. (2003) Radoviškiot govor. Skopje: Institut za makedonski jazik "Krste Misirkov". [Posebni izdanija, 40.]

- (2006) Meglenskiot govor. Skopje: Institut za makedonski jazik “Krste Misirkov". [Posebni izdanija, 46.]

Borisova, Ol'ga G. (2005) Kubanskie govory: Materialy k slovarju. Krasnodar: Kubanskij gos. universitet.

Boryś, Wiesław and Hanna Popowska-Taborska. (1994-2010) Stownik etymologiczny kaszubszczyzny. Warsaw: Slawistyczny Ośrodek Wydawniczy.

Bosak, Alena A. and Viktar M. Bosak. (2005-2006) Atlas havorak Pružanskaha rajona Bresckaj voblasci i sumežža (Verxnjaha Nad'jasel'dzja). Minsk: IVTs Minfina.

Bukrinskaja, Irina A. et al. (1994) Jazyk russkoj derevni: Škol'nyj dialektologičeskij atlas. Moscow: Aspect Press. Available online at: http://www.gramota.ru/ book/village/

Bun'ko, Natallja M. et al. (2015) Mova Sennenščyny: Dyjalektny sloŭnik u dvux tamax. Minsk: Belaruskaja navuka.

Burska-Ratajczyk, Beata. (2013) Realizacja funkcji perswazyjnej w tekstach gwarowych. Łódź: Uniwersytet Łódzki.

Canov, Ganko, Stojan Kovačev, and Totju Totevski. (1992) Terminologičen rečnik na zanajatite v trojanskija kraj. Sofia: Izdatelstvo na Bŭlgarskata akademija na naukite. 
Canova, Silvija. (1985) Govorŭt na selo Mandŭr, Mala Azija. Ph.D dissertation, Sofijski Universitet "Sv. Kliment Oxridski".

Čarnjakevič, Juryj V. (2009) Atlas havorak paŭnočna-ŭsxodnjaj Brestčyny. Minsk: Texnalohija.

Čirgić, Adnan. (2014) "Jezik crnogorskih muslimana". Matica crnogorska 59: 351-62.

. (2017) Dijalektologija crnogorskoga jezika. Cetinje: Fakultet za crnogorski jezik i književnost. [Biblioteka, posebna izdanja, knj. 19.]

Čomonev, Mladen. (1986) Govorŭt na selo Avren, Carigradsko. Ph.D dissertation, Sofijski Universitet "Sv. Kliment Oxridski".

Cossutta, Rado. $(2005,2006)$ Slovenski dialektološki leksikalni atlas Slovenske Istre (SDLA-SI) I, II. Koper: Univerza na Primorskem, Znanstveno-raziskovalno središče Koper/Zgodovinsko društvo za južno Primorsko.

Cvetanovski, Goce. (2004) Karšijačkiot govor-Skopsko: So posoben osvrt na sintaksata. Skopje: Institut na makedonski jazik "Krste Misirkov". [Posebni izdanija, 41.]

- (2010) Govorot na Makedoncite vo Mala Prespa (zapadnoprespanski govor). Skopje: Institut na makedonski jazik "Krste Misirkov". [Posebni izdanija, 66.]

Cvetkovski, Radovan. (2008) Rečnik na Demirhisarskiot govor. Skopje: Akademski pečat.

Danilovič, Mikalaj A. and Pavel U. Scjacko, eds. (1999) Sloŭnik rehijanal'naj leksiki Hrodzenščyny. Hrodna: HrDU.

Danyljuk, Oksana K. (1997) Slovnyk narodnyx heohrafičnyx terminiv Volyni. Lutsk: Nadstyr'ja.

Davkova-Gjorgieva, Svetlana. (2004) Leksikata na govorot na seloto Čiflidžik-Demirhisarsko (so kratok gramatički opis). Skopje: Institut na makedonskiot jazik "Krste Misirkov". [Posebni izdanija, 43.]

Dejna, Karol and Sławomir Gala, eds. (1998-2002) Atlas gwar polskich. Warsaw: Upowszechnianie Nauki-Oświata "UNO".

Delčeva, Tanja. (2004) “Towards a Lexicon of the Erkeč Dialect". Alexander, Ronelle and Vladimir Zhobov, eds. Revitalizing Bulgarian dialectology. UCIAS, 61-168. Available at: http://escholarship.org/uc/item/9hc6x8hp

Dialektologia polska. "Dialekty i gwary polskie. Kompendium internetowe pod red. Haliny Karaś". Last modified December 31, 2010. Available at: http:// www.dialektologia.uw.edu.pl/index.php.

Dinić, Jakša. (1988) "Rečnik timičkog govora". Srpski dijalektološki zbornik 34: 7-337. Belgrade: Srpska akademija nauka i umetnosti i Institut za srpski jezik.

. (1990) “Dodatak rečniku timočkog govora”. Srpski dijalektološki zbornik 36: 381-423. Belgrade: Srpska akademija nauka i umetnosti i Institut za srpski jezik. 
Dinić, Jakša. (1992) "Rečnik timičkog govora (drugi dodatak)". Srpski dijalektološki zbornik 38: 379-586. Belgrade: Srpska akademija nauka i umetnosti i Institut za srpski jezik.

- (2008) Timočki dijalekatski rečnik. Belgrade: Srpska akademija nauka i umetnosti i Institut za srpski jezik.

Dobreva, Diana. (1986) Govorŭt na selo Gorno Čamurli, Dobrudža. Ph.D dissertation, Sofijski Universitet "Sv. Kliment Oxridski".

Dragan, Zofia, ed. (2014) Co wieś, to inna pieśń. Stownik gwary Bukówca Górnego w Wielkopolsce i regionu Spisza w Małopolsce. Cracow: Stowarzyszenie Rozwoju Spisza i Okolicy, Wielkopolska Grupa Działania Kraina Lasów i Jezior.

Drul', Ihor M. (2006) Slovnyk hovirky sela Hrabovec' Stryjs'koho rajonu L'vivs'koji oblasti. Lutsk: Volyns'ka oblasna drukarnja.

Dybo, Vladimir A., Galina I. Zamjatina, and Sergej L. Nikolaev. (1990) Osnovy slavjanskoj akcentologii. Moscow: Nauka.

. (1993) Osnovy slavjanskoj akcentologii. Slovar'. Neproizvodnye osnovy mužskogo roda. Vyp. 1. Moscow: Nauka.

Dźwigoł, Renata. (2004) Polskie ludowe słownictwo mitologiczne. Cracow: Wydawnictwo Naukowe Akademii Pedagogicznej.

Faßke, Helmut, Helmut Jentsch, and Siegfried Michalk, eds. (1965-1996) Sorbischer Sprachatlas/Serbski rěčny atlas. Bautzen: VEB Domowina-Verlag.

Filin, Fedot P. and Fedor P. Sorokaletov, eds. (1965-) Slovar' russkix narodnyx govorov. 46 vols. Leningrad/St. Petersburg: Nauka. Available online at: https://iling.spb.ru/vocabula/srng/srng.html.

Filipi, Goran, and Barbara Buršić-Giudici. (1998) Istriotski lingvisički atlas/Atlas linguistico istrioto. Pula: ZUM

- (2013) Lingvistički atlas pomorske terminologije istarskih govora. Pula: Znanstvena udruga mediteran/Sveučilište Jurja Dobrile u Puli.

Friedman, Victor. (2011) "The Macedonian dialects of Albania". Review of Steinke and Ylli, vols. 1-3. Slavic and East European journal 55(4): 633-38.

Gancovskaja, Nina S. (2015) Slovar' govorov Kostromskogo Zavolžja: Meždureče Kostromy i Unži. Kostroma: KGU im. N.A. Nekrasova.

Gecova, Oksana G. and Elena A. Nefedova. (1980-) Arxangel'skij oblastnoj slovar'. 15 vols. Available at: http://www.philol.msu.ru/ dialectology/dictionary/.

Gerd, Aleksandr S., ed. (1992-) Leksičeskij atlas russkix narodnyx govorov: Materialy $i$ issledovanii. St. Petersburg: Institut lingvističeskix issledovanij RAN.

Glinka, Stanisław et al., eds. (1980-2012) Atlas gwar wschodniosłowiańskich Biatostocczyzny. 9 vols. Wrocław-Warsaw.

Grabka, Barbara. (2012) Obrzędowość roku kościelnego w gwarach polskich. Od adwentu do zapustów. Cracow: Instytut Języka Polskiego PAN.

Greenberg, Marc L. (1999) "Slovarček središkega govora (na osnovi zapisov Karla Ozvalda)". Slovenski jezik/Slovene linguistic studies 2: 128-75. 
Greenberg, Marc L. (2000) A historical phonology of the Slovene language. Heidelberg: Universitätsverlag Carl Winter.

Gregorčič, Jože. (2014) Kostelski slovar. Ljubljana: ZRC SAZU.

Gŭlŭbov, Luka. (2000) Leksikata na govora v s. Dobroslavci, Sofijsko. Sofia: Universtetsko izdatelstvo "Sv. Kliment Oxridski".

Gwary polskie. Przewodnik multimedialny pod red. Haliny Karaś. Last modified November 30, 2009. Available at: http://gwarypolskie.uw.edu.pl/.

Hanudel, Zuzana. (1981-2001) Linhvističnyj atlas ukrajinskyx hovoriv sxidnoji slovaččyny. Bratislava: Slovenské pedagogické nakladatel’stvo.

Hentschel, Gerd, Oleksandr Taranenko, and Sjarhej Zaprudski, eds. (2014) Trasjanka und Suržyk: Gemischte weißrussich-russische und ukrainisch-russische Rede. Berlin: Peter Lang.

Herman, Kostjantin F. (1994-1998) Atlas ukrajins'kyx hovirok Pivničnoji Bukovyny. Chernivtsi: Čas.

Hluxovceva, K. D. (2003) Linhvistyčnyj atlas leksyky narodnoho pobutu ukrajins'kyx sxidnoslobožans'kyx hovirok. Luhansk: Alma-Mater.

Holub, Zbyněk and Marc L. Greenberg. (2013) "A circum-Pannonian word-prosodic parallel: Paroxytonic accent in the South-West Bohemian dialect". Jezikoslowni zapiski 19(2): 11-26. Available at: http://hdl.handle.net/1808/13078.

Horodyska-Gadkowska, Halina, Anna Kowalska, and Alina Strzyżewska-Zaremba, eds. (1971-1992) Atlas gwar mazowieckich. Wrocław: Zakład Narodowy im. Ossolińskich.

Houtzagers, Peter. (1999) The Kajkavian dialect of Hidegseg and Fertóhomok. Amsterdam, Atlanta: Rodopi. [Studies in Slavic and general linguistics, 27.]

Ivančič Kutin, Barbara. (2007) Slovar bovškega govora. Ljubljana: ZRC SAZU.

Ivanova. Anna A. (2008) Mikrotoponimija Mozyrskogo Poles'ja. Mazyr: MGPU. Janów, Jan. (2001) Stownik huculski. Cracow: Wydaw. Nauk. DWN.

JSL Editors. (2012) "Index to volumes 1-20". Journal of Slavic linguistics 20(2): 311-36.

Kalnyn', L. E. and T.V. Popova. (1993) "Fonetika dvux bolgarskix govorov, functionirujuščix v uslovijax raznoj jazykovoj situacii". Issledovanija po slavjanskoj dialektologii, 2: 5-191. Moscow: Rossijskaja akademija nauk. Institut slavjanovedenija i balkanistiki.

Kalsbeek, Janneke. (1998) The Čakavian dialect of Orbanići near Žminj in Istria. Amsterdam, Atlanta: Rodopi. [Studies in Slavic and General Linguistics, 25.]

Kapović, Mate. (2015) Povijest hrvatske akcentuacije: Fonetika. Zagreb: Matica hrvatska.

Karanfilovski, Maksim. (2013) Enidževardarskiot govor. Skopje: Filološki fakultet "Blaže Koneski".

Karaś, Halina. (2011) Polska leksykografia gwarowa. Warsaw: Wydział Polonistyki Uniwersytetu Warszawskiego. 
Karaś, Mieczysław, et al., eds. (1979-) Stownik gwar polskich. Instytut Języka Polskiego PAN; Wrocław: Zakład Narodowy im. Ossolińskich.

Kąś, Józef. (2003) Stownik gwary orawskiej. Cracow: Księgarnia Akademicka. Keremedčieva, Slavka. (2007) Koprivštica: Istorija i ezik. Sofia: Multiprint.

Keremedčieva, Slavka, et al. (2012) Erkeč: Pametta na ezika. Tradicii i ustojčivi tendencii v edin arxaičen bŭlgarski govor-govora na selo Erkeč (dnes Kozičino), Pomorijsko. Sofia: Multiprint, Institut za bŭlgarski ezik-BAN. Fondacija "Bŭlgarska Pamet".

Király, Péter, ed. (1993) Atlas slovenských nárečív Mad’arsku/Atlas der slowakischen Mundarten in Ungarn. Budapest: Slovenský ústav Zväzu Slovákov v Mad’arsku.

Kirillova, Tat'jana V. and Novikova, Ljudmila N. (2002-2006) Tematičeskij slovar' govorov Tverskoj oblasti. 5 vols. Tver: TvGU.

Kiš, Marijana. (1996) Dijalektnata leksika od oblasta na rastitelniot svet. Skopje: Institut za makedonski jazik "Krste Misirkov". [Posebni izdanija, 22.]

Kitanova, Marija. (1981) Govorŭt na selo Karaač, Odrinsko. Ph.D dissertation, Sofijski Universitet "Sv. Kliment Oxridski".

Klimuc', Stanislava V., et al. (2004) Sloŭnik mikrataponimaŭ Mahilëŭščyny. Mogilev: MDU.

Kolesnikova, Svetlana V. (2003) Slovar' russkix govorov Čuvašskoj Respubliki. Cheboksary: Izd-vo Čuvašskogo universiteta.

Kondratiuk, Michał. (2014) Gwarowe nazwy miejscowości Białostocczyzny w układzie alfabetycznym. Białystok: Fundacja im. Księcia Konstantego Ostrogskiego

Kotova, N.B. (1960-2000) Gorno Pole, Dupniško. Rečnik. Sofia: Družestvo IOS.

Křen, Michal. (2017) “Jaké korpusy zpřístupňuje Český národní korpus?” Last modified April 26, 2017. Available at: http://wiki.korpus.cz/doku.php/cnk:uvod.

Kroxmaljuk, Dmytro. (2015) Slovnyk hovirky sela Senderivka ta inšyx naselenyx punktiv Mohilivs'koho Prynistrov'ja. Kiev: Litopys-XX.

Kučuk, Ivan M. and Maljuk, Anton K. (2000) Paleski sloŭnik: Lel'čycki rajon. Mazyr: MazDPI imja N. K. Krupskaj.

Kurek, Halina. (1990) Metodologia socjolingwistycznego badania fonetyki języka mówionego środowisk wiejskich (na przykładzie kilku wsi Beskidu Niskiego). Cracow: Uniwersytet Jagielloński.

Kurkina, Ljubov' V. (1992) Dialektnaja struktura praslavjanskogo jazyka po dannym južnoslavjanskoj leksiki (Narečna struktura praslavanskego jezika v luči južnoslovanske leksike). Ljubljana: Slovenska akademija znanosti in umetnosti. [Razred za filološke in literarne vede. Classis I: Philologia et litterae, 38.]

Kurylenko, Viktor N. (2004) Atlas leksyky tvarynnyctva u polis'kyx dialektax. Hlukhiv: RVV HDPU.

Labocha, Janina. (1997) Polsko-czeskie pogranicze na Ślasku Cieszyńskim. Zagadnienia językowe. Cracow: Wydawnictwo Naukowe. 
Labroska, Veselinka. (2003) Govorot na seloto Kula-Sersko. Skopje: Institut za makedonski jazik "Krste Misirkov". [Posebni izdanija, 38.]

- (2008) Kičevskiot govor. Skopje: Institut za makedonski jazik “Krste Misirkov". [Posebni izdanija, 50.]

Labroska, Veselinka, Ubavka Gajdova, Svetlina Davkova-Ǵorgieva, Goce Cvetkanovski, and Darko Tomovski. (2012) Vratničko-pološkite govori, duhovna riznica. Skopje: Institut za makedonski jazik "Krste Misirkov". [Posebni izdanija, 74.]

Langston, Keith. (2006) Čakavian prosody: The accentuation of the Čakavian dialects of Croatian. Bloomington: Slavica.

Latta, Vasil' P. (1991) Atlas ukrajins'kyx hovoriv sxidnoji Slovaččyny. Bratislava: Slovacké pedahohičné vydatelstvo.

Levancevič, Lena V. (1993-2001) Atlas havorak Bjarozaŭskaha rajona bresckaj voblasci. 4 vols. Brest: Brescki dzjaržaŭny pedinstytut.

Lisac, Josip. (2003) Hrvatska dijalektologija 1. Hrvatski dijalekti i govori štokavskog narječja i hrvatski govori torlačkog narječja. Zagreb: Golden Marketing.

—. (2009) Hrvatska dijalektologija 2. Čakavsko narječje. Zagreb: Golden Marketing.

Lundberg, Grant H. (2013) Dialect leveling in Haloze, Slovenia. Maribor: Mednarodna knjižna zbirka ZORA. [Zora, 91.] Available at: http://hdl.handle. net/1808/12462

Mackevič, Juzefa, Alena I. Hrynaveckene, and Jaŭhenija M. Ramanovič. (19791986) Sloŭnik belaruskix havorak paŭnočna-zaxodnjaj Belarusi i jaje pahraničča. 5 vols. Minsk: Navuka i texnika.

Malenko, Biljana. (2012) Štipskiot govor. Skopje: Institut za makedonski jazik "Krste Misirkov". [Posebni izdanija, 72.]

Marešić, Jela and Mira Menac-Mihalić. (2008) Frazeologija križevačko-podravskih kajkavskih govora s rječnicima. Zagreb: Institut za hrvatski jezik i jezikoslovlje.

Marinska, R. (1991) Devesilskijat govor. Fonetika i morfologija. Kandidatska dissertacija (unpublished). Sofijski universitet "Sv. Kliment Oxridski".

Markovik', Marian. (2007) Aromanskiot i makedonskiot govor od ohridsko-struškiot region: vo balkanski kontekst. Skopje: Makedonska akademija na naukite i umetnostite.

. (2012) Digitalni resursi na makedonskite dijalekti. Available at: http://dijalekti.manu.edu.mk.

Martynova, Hanna I. (2003) Seredn'onaddniprjans'kyj dialekt: Fonolohija i fonetyka. Cherkasy: Tjasmin.

Matveev, Aleksandr K., ed. (2001-) Slovar' govorov russkogo Severa. Ekaterinburg: Izd-vo Ural'skogo universiteta.

Matvijas, Ivan H., Jaroslava V. Zakrevs'ka, and Anton M. Zales'kyj, eds. (19842001) Atlas ukrajins'koji movy. 3 vols. Kiev: Naukova dumka. 
Matvijiv, Mykola D. (2013) Slovnyk hovirok central'noji Bojkivščyny. Kyiv/Simferopol: Vydavnyctvo 'Nata'.

Mixaleva, Tamara V. (2013) Slovar' russkix govorov na territorii Respubliki Mordovija. St. Petersburg: Nauka.

Mladenov, Asen. (2009) Trŭnskite dumi. Rečnik na regionalnija govor. Sofia: DTM.

Mladenov, Maksim. (1975) "Rasprostranenie nekotoryx karpatizmov v bolgarskix govorax". Slavjanskoe i balkanskoe jazykoznanie. Problemy interferencii i jazykovyx kontaktov. Moscow: Nauka, 220-35.

. (2008) Dialektologija. Balkanistika. Etnolingvistika. Lingvistično nasledstvo. Sofia: Universitetsko izdatelstvo "Sv. Kliment Oxridski". [With some editing and collaboration by Darina and Olga Mladenova.]

Mladenova, Darina. (2006) Zvezdnoto nebe nad nas. Etnolingvistično izsledvanie na balkanskite narodni astronimi. Sofia: Akademično izdatelstvo "Prof. Marin Drinov".

- (2010) "From linguistic geography to areal linguistics: A case study of tomatoes in the Eastern Balkans". Donald L. Dyer, Olga Mladenova, and Tom Priestly, eds. The Banff Papers. The $16^{\text {th }}$ Balkan and South Slavic conference. Banff, Alberta, Canada, May 1-4, 2008. Columbus, OH: Slavica, 181-237. [Balkanistica, 23]

. (2016) Ot lingvistična geografija kŭm arealna lingvistika. Teorija i praktika $n a$ analiza na kŭsni javlenija v bŭlgarskija ezik. Nazvanijata na domata i patladžana. Sofia. [Littera et Lingua Series Dissertationes, 9.]

Mladenova, Olga M. (2007) Definiteness in Bulgarian. Modelling the processes of language change. Berlin, New York: Mouton de Gruyter. [Trends in linguistics. Studies and monographs, 182.]

Mladenova, Olga and Darina Mladenova. (2001-2013) Transdanubian electronic corpus. Otvŭddunavski elektronen korpus. Dopŭlnenie kŭm "Bŭlgarskite govori $v$ Rumŭnija" ot M. Mladenov. Available at: http://www.corpusbdr.info.

Moseev, Ivan I. (2005) Pomor'ska govorja: kratkij slovar' pomorskogo jazyka. Arkhangelsk: "Belye al'vy", "Pravda Severa". Available online at: http:// www.fyodors.ru/pdf/dictionary.pdf.

Mŭžlekova, M. (1990) Rečnik na starobŭlgarski dumi v dnešnite bŭlgarski govori. Sofia: Izd. Bŭlgarska akademija na naukite.

- (1994) Edinstvoto na starobŭlgarskija ezik na leksikalno ravnište. Sofia: Akademično izdatelstvo "Prof. Marin Drinov".

Myznikov, Sergej A. (2005) Russkie govory srednego Povolžja. Čuvašskaja respublika. Respublika Marij El. St. Petersburg: Nauka.

Nikčević, Vojislav P. (2009) Istorija crnogorske knjižeonosti: Od početaka pismenosti do XII. vijeka. Cetinje: Institut za jezik i jezikoslovlje.

Nikolaev, Sergej L. (2008) "Balkano-karpatskie izoglossy kak relikt pozdnepraslavjanskogo lingvističeskogo landšafta". Anna A. Plotnikova, Elena S. Uzeneva, Veronika V. Usačeva, et al., eds. Karpato-balkanskij dialek- 
tnyj landšaft. Jazyk i kul'tura. Vypusk 1. Pamjati Galiny Petrovny Klepikovoj. Moscow: Institut Slavjanovedenija RAN, 125-39.

Nikolaev, Sergej L. (2012) “Vostočnoslavjanskie refleksy akcentnoj paradigmy $d$ i indoevropejskie sootvetstvija slavjanskim akcentnym tipam suščestvitel'nyx mužskogo roda s o- i u-osnovami". Karpato-balkanskij dialektnyj landšaft. Jazyk i kul'tura. Vol. 2, 2009-2011. Moscow: Institut Slavjanovedenija RAN, 32-190.

Nikolaev, Sergej L. and Marfa N. Tolstaja. (2001) Slovar' karpatoukrainskogo torun'skogo govora s grammatičeskim očerkom i obrazcami tekstov. Moscow: Institut slavjanovedenija RAN. Available online at: http://ablaut.narod.ru/torun/ torun.htm.

Nikolaev, Sergej L., Aleksandra V. Ter-Avanesova, and Marfa N. Tolstaja. (2013) "Vokalizm polesskix govorov v praslavjanskoj perspektive". Svetlana M. Tolstaja and Aleksandr M. Moldovan, eds. Slavjanskoe jazykoznanie. XV Meždunarodnyj s'jezd slavistov. Minsk, 2013 g. Doklady rossijskoj delegacii. Moscow: "Indrik," RAN, 99-141.

Novak, Vilko, and Milena Hajnšek-Holz. (2006) Slovar stare knjižne prekmurščine. Ljubljana: ZRC.

Nykončuk, Mikola (1994) Leksyčnyj atlas pravoberežnoho Polissja. Kiev: Ministerstvo Ukrajiny v spravax zaxystu naselennja vid naslidkiv avariji Čornobyl'skij AES.

OKDA = Obščekarpatskij dialektologičeskij atlas. Available at: http://www.inslav.ru/.

OLA = Obščeslavjanskij lingvističeskij atlas. Available at: http://www.slavatlas.org/.

Omel'kovec', Ruslana S. (2003) Atlas zaxidnopolis'kyx nazv likars'kyx roslyn. Lutsk: Veža.

Pavel, Avgust. (2013) Prekmurska slovenska slovnica. Vend nyelvtan. Maribor: Mednarodna založba Oddelka za slovanske jezike in književnosti, Filozofska fakulteta. [Zora, 100.]

Pavlova, Neda. (1981) Lozengradskijat govor. Ph.D dissertation, Sofijski Universitet "Sv. Kliment Oxridski".

Peev, Kosta. (1999) Rečnik na makedonskite govori vo jugoistočniot egejski del. Vols. 1-6. Skopje: Studentski zbor.

Peti-Stantić, Anita. (2008) Jezik naš i/ili njihov. Vježbe iz poredbene povijesti južnoslovenskih standardizacijskih procesa. Zagreb: Srednja Europa.

Pimenova, T. A. (2004-) Slovar' kurskix govorov. Kursk: Izd-vo KGU. [Most recent volume, Kaba-Kyčka, 2015.]

Plotnikova, A. A. (2004) Etnolingvističeskaja geografija Južnoj Slavii. Moscow: Izdatel'stvo "Indrik".

Podjukov, Ivan A. (2010-2012) Slovar' russkix govorov Južnogo Prikam'ja. Perm': PGPU.

Popova, Tat'jana V. (1995) Vostočnoslavjanskie izoglossy. Moscow: Nauka.

Popova, Tat'jana V., ed. $(1998,2000,2006)$ Vostočnoslavjanskie izoglossy. Moscow: Institut Russkogo jazyka im. V. V. Vinogradova. 
Pronk, Tijmen. (2009) The Slovene dialect of Egg and Potschach in the Gailtal, Austria. Amsterdam: Rodopi.

Pšeničnova, Nadežda N. (2008) Lingvističeskaja geografija (po materialam govorov). Moscow: Azbukovnik.

Radeva, Vasilka, Todor Bojadžijev, Vladimir Žobov, Georgi Kolev, Maksim Mladenov, and Darina Mladenova, eds. (2012) Ideografskija dialekten rečnik na bŭlgarskija ezik. Tom 1, $A$-D. Sofia: Bŭlgarski bestselŭr-Nacionalen muzej na bŭlgarskata kniga i poligrafija.

Radulić, Ladislav. (2002) Rječnik rivanjskoga govora. Zadar: Matica hrvatska Zadar.

Rieger, Janusz, ed. (1996) A lexical atlas of the Hutsul dialects of the Ukrainian language. Warsaw: Semper; Cambridge, MA: Harvard University Press.

Ripka, Ivor, and Adriana Ferenčíková, eds. (1994-) Slovník slovenských nárečí. Bratislava: Veda.

Roki-Fortunato, Andro. (1997) Knjiga viškoga govora. Toronto: Libar Publishing. Sabadoš, Ivan. (2008) Slovnyk zakarpats'koji hovirky sela Sokyrnycja Xusts'koho rajonu. Uzhhorod: Lira.

Saharovs'kyj, Anatolij. (2011-2013) Materialy do dialektnoho slovnyka central'noji Slobožanščyny (Xarkivščyny). Kharkiv: XNU imeni V. N. Karazina.

Sekulić, Ante. (2005) Rječnik govor bačkih Hrvata. Zagreb: Institut za hrvatski jezik i jezikoslovlje.

Seržant, Ilja A. and Björn Wiemer, eds. (2014) Contemporary approaches to dialectology: The area of North, Northwest Russian and Belarusian vernaculars. Bergen: John Grieg AS. [Slavica Bergensia, 13.]

Šimková, Mária. (2013) “Slovenský národný korpus a korpusová lingvistika na Slovensku po roku 2002". Slovenská reč 78(6): 354-67. Available at: http:// www.juls.savba.sk/ediela/sr/2013/6/SR20136.pdf.

Šklifov, Ivan and Ekaterina Šklifova. (2003) Bŭlgarski dialektni tekstove ot Egejska Makedonija. Sofia: Akademično izdatelstvo "Prof. Marin Drinov".

Škofic, Jožica, et al. (2011) Slovenski lingvistični atlas. 1, Človek (telo, bolezni, družina) [Kartografsko gradivo]. Ljubljana: Založba ZRC.

Škofic, Jožica, et al. (2016) Slovenski lingvistični atlas. 2, Kmetija [Kartografsko gradivo]. Ljubljana: Založba ZRC.

Slovník náreči českého jazyka. (2016-) Brno: Dialektologické oddělení Ústavu pro jazyk český AV ČR. Available at: http://sncj.ujc.cas.cz/.

Šmiger, Roland. (1998) Nestramski govor: Doprinos južnoslovenskoj dijalektologiji. Munich: Verlag O. Sagner. [Slavistische Beiträge, 364.]

Sobierajski, Zenon, ed. (1979-2005) Atlas języka i kultury ludowej Wielkopolski. Poznań: Uniwersytet Adama Mickiewicza; Wrocław: Zakład Narodowy im. Ossolińskich.

Sobolev, Andrej N. (2001) Bolgarskij širokolykskij govor. Sintaksis. Leksika duxovnoj kul'tury. Teksty. Rossijskaja akademija nauk. Institut lingvističeskix issledovanij. Philipps-Universität Marburg. Institut für Slawische Philol- 
ogie. Marburg an der Lahn: Biblion Verlag. [Malyj dialektologičeskij atlas balkanskix jazykov. Kleiner Balkansprachatlas.]

Sobolev, Andrej N. (2003a) Malyj dialektologičeskij atlas balkanskix jazykov. Probnyj vypusk. Muunich: Biblion Verlag.

. (2003b) Malyj dialektologičeskij atlas balkanskix jazykov. Serija leksičeskaja. Tom 1. Leksika duxovnoj kul'tury. Munich: Biblion Verlag.

- (2005) Malyj dialektologičeskij atlas balkanskix jazykov. Serija leksičeskaja.

Tom 2. Čelovek. Sem'ja. Munich: Biblion Verlag.

- (2006) Malyj dialektologičeskij atlas balkanskix jazykov. Serija leksičeskaja.

Tom 3. Životnovodstvo. Munich: Biblion Verlag.

- (2009) Malyj dialektologičeskij atlas balkanskix jazykov. Serija leksičeskaja.

Tom 4. Polevodstvo. Ogorodničestvo. St. Petersburg: Nauka, Munich: Otto Sagner Verlag.

- (2013) Osnovy lingvokul'turnoj antropogeografii Balkanskogo poluostrova.

Tom 1. Homo balcanicus i ego prostranstvo. St. Petersburg: Nauka, Munich:

Otto Sagner Verlag.

Srebranov, Rumen. (2007) Čečkijat govor. Sofia: Akademično izdatelstvo "Prof. Marin Drinov".

Steenwijk, Han. (1992) The Slovene dialect of San Giorgio/V Bili. Amsterdam: Rodopi.

Steinke, Klaus and Zhelal Ylli. (2007) Die slavischen Minderheiten in Albanien (SMA). 1. Teil. Prespa-Vërnik-Boboshtica. (With CD). Munich: Verlag Otto Sagner. [Slavistische Beiträge, 458.]

- (2008) Die slavischen Minderheiten in Albanien (SMA). 2. Teil. GollobrdaHerbel-Kërchisti i Epërm. (With CD). Munich: Verlag Otto Sagner. [Slavistische Beiträge, 462.]

- (2010) Die slavischen Minderheiten in Albanien (SMA). 3. Teil. Gora. (With CD). Munich: Verlag Otto Sagner. [Slavistische Beiträge, 474.]

Stoevska-Denčeva, Elenka. (2004) Krivopalanečkiot govor. Skopje: Institut za makedonski jazik "Krste Misirkov". [Posebni izdanija, 42.]

Stojčev, T. (1965) "Rodopski rečnik". Bŭlgarska dialektologija 2: 119-315.

. (1970) "Rodopski rečnik". Bŭlgarska dialektologija 5: 153-220.

. (1983) "Rodopski rečnik". Rodopski sbornik 5: 287-353.

Stupins'ka, Halyna F. and Jaryna V. Bitkivs'ka. (2012) Frazeolohyčnyj slovnyk lemkivs'kyx hovirok. Ternopil: Navčal'na knyha-Bohdan.

Šylo, Havrylo (2008) Naddnistrjans'kyj rehional'nyj slovnyk. Lviv: Instytut ukrajinoznavstva im. I. Kryp'jakeviča.

Takač, Ferdinand. (2004) Rječnik sela Hrvatski Grob. Zagreb: Institut za hrvatski jezik i jezikoslovlje.

Tolstaja, Marfa N. (2012) “Karpatoukrainskie enklitiki v južnoslavjanskoj perspective". A. A. Plotnikova, E. S. Uzeneva, M. N. Tolstaja, O. V. Trefilova. Karpato-balkanski dialektnyj landšaft. Jazyk i kul'tura. Vol. 2, 2009-2011. Moscow: Institut slavjanovedenija. RAN, 190-211. 
Topalova, Svetlana. (2009) Govorŭt na selo Kalčevo, Bolgradsko, Besarabija. Rečnik. Odessa: Druk. [Bŭlgarskite govori v Ukrajna, 5.]

Topolinjska, Zuzana V. (2014) "Dali e na povidok renesansa na dialektologijata (so poseben osvrt kon pozicija na makedonskiot jazik)". Južnoslovenski filolog LXX: 9-15.

Turčyn. Jevheniji. (2011) Slovnyk sela Tylyč na Lemkivščyni. Lviv: Ukrajins'ka akademija drukarstva.

Užčenko, Viktor D. (2013) Frazeolohičnyj slovnyk sxidnoslobožans'kyx i stepovyx hovirok Donbasu. Luhansk: DZ LNU imeni Tarasa Ševčenko.

Vačeva-Xoteva, Marija and Slavka Keremedčieva. (2000) Govorŭt na selo Zarovo Solunsko. S ogled kŭm leksikalnata mu sistema. Sofia: Multiprint EOOD.

Vakarelska-Čobanska, Donka. (2002) Samokovskijat govor. Sofia: Akademično izdatelstvo "Prof. Marin Drinov". [Trudove po bŭlgarska dialektologija i istorija na bŭlgarski ezik, 1.]

—. (2005) Rečnik na samokovskija govor. Sofia: Akademično izdatelstvo "Marin Drinov".

Vendina, Tat'jana I. (2009) Russkie dialekty v obščeslavjanskom kontekste (leksika). Moscow: Institut slavjanovedenija RAN.

- (2014) Tipologija leksičeskix arealov Slavii. Moscow: Institut Slavjanovedenija RAN.

Veštart, Halina F. et al, eds. (2008) Leksika havorak belaruskaha prypjackaha Palessja. Atlas. Sloŭnik. Minsk: Prava i èkonomika.

Vidoeski, Božidar. (2000) Tekstovi od dijalektite na makedonskiot jazik. Skopje: Institut za makedonski jazik "Krste Misirkov".

Vitanova, Marija. (1985) Govorŭt na selo Enikjoj, Ksantijsko. Ph.D dissertation, Sofijski Universitet "Sv. Kliment Oxridski".

Vuković, Siniša. (2001) Ričnik selaškega govora. Split: Laus.

Weiss, Peter (1998) Slovar govorov Zadrečke doline med Gornjim Gradom in Nazarjami (A-H). Ljubljana: Založba ZRC.

Wróblewski, Mikołaj. (2008) Słownik gwary bielsko-podlaszkiej: na podstawie języka wsi Chraboty oraz przedmieścia Studziwody. Bielsk-Podlaski: Stowarzyszenie Muzeum Małej Ojczyzny w Studziwodach.

Wronicz, Jadwiga. (2006) "Amatorskie słowniki gwarowe". Joanna Okoniowa, ed. Studia dialektologiczne. Cracow: Lexis, 171-80.

Wronicz, Jadwiga, ed. (2009) Mały stownik gwar polskich. Cracow: Lexis.

Wyderka, Bogusław, ed. (2000-) Słownik gwar ślaskich. Opole: Państwowy Instytut Naukowy, Instytut Śląski w Opolu.

Xobzej, Natalija V. (2002) Hucul's'ka mifolohija: Etnolinhvistyčnyj slovnyk. Lviv: Instytut ukrajinoznavstva im. I. Kryp'jakeviča.

—. (2013) Hucul's'ki svity: Leksykon. Lviv: Instytut ukrajinoznavstva im. I. Kryp'jakeviča NAN Ukrajiny.

Zajc, Marko. (2006) Kje se slovensko neha in hrvaško začne. Slovensko-hrvaška meja $v$ 19. in na začetku 20. stoletja. Ljubljana: Modrijan. 
Zajka, Ales'. (2011) Dyjalektny sloŭnik Kosaŭščyny. Slonim: Slonimskaja drukarnja.

. (2014) Frazealahičny sloŭnik Kosaŭščyny. Brest: Bresckaja drukarnja.

Zakhutska, Oksana. (2015). Polszczyzna drobnoszlacheckiej wsi Siaberka na Wotyniu. Warsaw: DiG.

Zaręba, Alfred, ed. (1969-1996) Atlas językowy Ślaska. Warsaw: Energeia; Warsaw/Cracow: PWN.

Zdobnova, Zoja P. (2000) Atlas russkix govorov Baškirii. 2 vols. Ufa: Baškirskij gosudarstvennyj universitet.

Zdobnova, Zoja P., ed. (2008) Slovar' russkix govorov Baškirii: A-Ja. Ufa: Gilem.

Zinčuk, Ruslana S. (2010) Atlas slovozminy imennykiv u zaxidnopolis'kyx hovirkax. Lutsk: Redakcijno-vydavnyčyj viddil Volyns'koho nacional'noho universytetu imeni Lesi Ukrajinki.

Zlatković, Dragoljub. (1988) "Poslovice i poređenja u pirotskom govoru“. Srpski dijalektološki zbornik 34: 337-683.

_. (1989) "Frazeologija straha i nade u pirotskom govoru". Srpski dijalektološki zbornik 35: 175-457.

__. (1990) "Frazeologija omalovaživanja u pirotskom govoru". Srpski dijalektološki zbornik 36: 423-740.

Zlobin, Lidzija I. et al. (2012-2014) Rehijanal'ny sloŭnik Vicebščyny. 2 vols. Vitebsk: UA “BDU imja P. M. Mašerava.

Žobov, Vladimir. (2004) Zvukovete v bŭlgarskija ezik. Sofia: Sema RSH. [Verba magistri series.]

Marc L. Greenberg

University of Kansas

mlg@ku.edu

Krzysztof E. Borowski

University of Kansas

borowski@ku.edu

Joseph Schallert

University of Toronto

joseph.schallert@utoronto.ca

Curt F. Woolhiser

Brandeis University

cwoolhis@brandeis.edu 